\title{
Polycystic ovarian syndrome: rs1799752 polymorphism of ACE gene
}

\author{
D Mariangela Torreglosa Ruiz Cintra ${ }^{1}$ \\ Marly Aparecida Spadotto Balarin ${ }^{2}$ \\ Sarah Cristina Sato Vaz Tanaka ${ }^{3}$ \\ Vanessa lorrana Mota da Silva ${ }^{4}$ \\ Alessandra Bernadete Trovó de Marqui ${ }^{5}$ \\ Elisabete Aparecida Mantovani Rodrigues de Resende ${ }^{6}$ \\ Marco Fábio Prata Lima \\ Mariana Kefálas Oliveira Gomes ${ }^{8}$
}

\begin{abstract}
1. Professor of the Institute of Exact and Natural Sciences and Education of the Federal University of Triângulo Mineiro, Uberaba, MG, Brasil 2. Professor of the Institute of Biological and Natural Sciences of the Federal University of Triângulo Mineiro, Uberaba, MG, Brasil 3. Doctorate Student of the Institute of Biological and Natural Sciences of the Federal University of Triângulo Mineiro, Uberaba, MG, Brasil 4. Student of the Biological Sciences course of the Federal University of Triângulo Mineiro, Uberaba, MG, Brasil 5. Professor of the Institute of Biological and Natural Sciences of the Federal University of Triângulo Mineiro, Uberaba, MG, Brasil 6. Professor of the Institute of Sciences and Health of the Federal University of Triângulo Mineiro, Uberaba, MG, Brasil 7. Professor of the Institute of Sciences and Health of the Federal University of Triângulo Mineiro, Uberaba, MG, Brasil 8. Professor of the Institute of Sciences and Health of the Federal University of Triângulo Mineiro, Uberaba, MG, Brasil
\end{abstract}

http://dx.doi.org/10.1590/1806-9282.64.11.1017

\section{SUMMARY}

PURPOSE: To investigate the contribution of the deletion polymorphism and insertion (rs1799752) of the angiotensin converting enzyme (ACE) gene in the aetiology of Polycystic Ovarian Syndrome (PCOS).

METHODOLOGY: 97 women diagnosed with PCOS who received care at the Gynaecology and Obstetrics clinic of the Hospital das Clínicas of UFTM, participated in this study. The control group consisted of 94 women. All participants were submitted to the collection of $10 \mathrm{~mL}$ of whole blood and the genomic DNA was obtained by the saline extraction method. The genotyping of the samples was performed by means of the Polymerase Chain Reaction (PCR). The statistics analyses were performed by descriptive analysis, univariate analysis and logistic regression model. The results were presented in odds ratio (OR) and confidence interval of 95\% (Cl-95\%), with a significance level of $5 \%(p \leq 0.05)$.

RESULTS: There were no statistical differences between patients and controls for the genotypic $(\chi 2=1.52, p=0.47)$ and allelic frequencies $(\chi 2=0.21, p=0.76)$. The distribution of the genotypic frequency is not in HWE for patients $(\chi 2=18.80, p<0.05)$ and for controls $(\chi 2$ $=6.85, p<0.05)$. In relation to the risk factors for the syndrome, the history of familial PCOS is more frequent between women with the syndrome.

CONCLUSION: In the study population, there was no association between I/D polymorphism of the ACE gene and PCOS.

KEYWORDS: Polycystic ovary syndrome. Ovarian cysts. Polymorphism, genetic. Angiotensin.

\section{INTRODUCTION}

Polycystic ovarian syndrome (PCOS) is one of the most common endocrine disorders in women's reproductive age and it is the most frequent cause of chronic anovulation and infertility'. The criteria for the diagnosis of PCOS include at least two of the following manifestations: oligovulation or chronic anovulation, clinical and/or laboratory aspects of hyperandrogenism and presence of ovarian cysts visualized by ultrasound examination. ${ }^{2}$

Although the aetiology of PCOS remains undeter-

DATE OF SUBMISSION: 22-Feb-2018

DATE OF ACCEPTANCE: 25-Feb-2018

Corresponding Author: Mariangela Torreglosa Ruiz Cintra

Instituto de Ciências Exatas, Naturais e Educação (Icene) - Universidade Federal do Triângulo Mineiro (UFTM)

Av. Dr. Randolfo Borges Jr., 1400, Uberaba, MG, Brasil - CEP 38064-200 - Tel: +55 (34) 3331-3143

E-mail: mariangelatorreglosa@hotmail.com 
mined, it is considered a multifactorial disease, with several metabolic, endocrine, environmental and genetic alterations. ${ }^{3}$

Among the metabolic alterations present, insulin resistance and hyperinsulinemia are evident in the majority of those affected. PCOS increases the risk for type II diabetes mellitus, gestational diabetes and other complications related to pregnancy, venous thromboembolism, cerebrovascular and cardiovascular events, and endometrial cancer. ${ }^{4}$ Among the environmental risk factors, smoking and alcohol habits are related to increased risk for reduced fertility, complications during pregnancy, miscarriages, cardiovascular disease, and insulin resistance in PCOS. ${ }^{5}$ The prevalence of PCOS is higher among first degree relatives, thus indicating that the interaction between multiple genes and environmental factors is probably necessary for the development of PCOS. This hypothesis has given rise to a large number of studies aimed at investigating the role that genetic mechanisms play in the aetiology of the syndrome. ${ }^{6}$

Among the metabolic pathways, the ovarian renin-angiotensin system acts on follicle development/ atresia and ovulation and in secretion of steroid hormones. The proper functioning of this system is necessary for normal reproduction, and its activity is regulated by gonadotrophins and it depends on the activation of proteases in the area of follicle growth. Angiotensin and its receptors are distributed in the ovarian follicles, in the preovulatory teak, in the granulosa cells and in the cells of the post-ovulatory granulosa layer and they regulate steroid production. Abnormal function of this system may be associated with infertility and PCOS. ${ }^{7}$

Angiotensin-converting enzyme (ACE), a key enzyme in the renin-angiotensin system (RAS), can convert angiotensin I to angiotensin II, which is the main effector peptide of this system. The angiotensin converting enzyme gene is located on chromosome 17 (17q23.3) and has more than 160 polymorphisms described. Individual variations in ACE concentration are associated with an insertion (I)/deletion (D) polymorphism of $287 \mathrm{bp}$ at intron 16 of the gene (rs1799752). The DD genotype is associated with high plasma levels of the protein, the DI genotype at intermediate levels and II at low plasma protein levels, evidencing that this polymorphism may influence the renin-angiotensin system and its abnormal function may be associated with PCOS..$^{7-9}$ This polymorphism has already been associated with some clinical con- sequences of PCOS, such as hypertension ${ }^{10,11}$, diabetes $^{10}$ and metabolic syndrome. ${ }^{12}$

Despite the importance of the ACE gene in ovarian physiology, studies published on polymorphisms in this gene and its susceptibility to PCOS are scarce and have shown controversial results. A meta-analysis involving six studies with 1,451 patients and 773 controls suggested that the polymorphism is associated with the risk of developing PCOS in Caucasian women. ${ }^{13} \mathrm{In}$ addition, there are no studies on this polymorphism and PCOS in Brazilian women. In view of the above, this study aimed to determine the frequency of the insertion (I)/deletion (D) polymorphism of the ACE gene (rs1799752) in patients with PCOS and to compare it with a control population in order to verify the association of this polymorphism with the syndrome.

\section{METHODS}

This case control study was approved by the Research Ethics Committee of the Federal University of Triângulo Mineiro, protocol 1796, and all the participants signed the Free and Informed Consent Term. The sample consisted of 191 women (97 women of reproductive age with no history of hyperandrogenism, menstrual dysfunction, infertility or sonographic signal of PCOS, who constituted the control group and 94 women diagnosed with PCOS). The Rotterdam criteria for the diagnosis of PCOS were used. ${ }^{14}$

Women with Cushing's Syndrome, 21-hydroxyalase deficiency, thyroid dysfunction, hyperprolactinemia, diabetes, androgen-secreting tumours, and current or six-month use of oral contraceptives, antiandrogens, statins, glucocorticoids or infertility medications were excluded from this study. All participants in the study answered a questionnaire for the collection of sociodemographic and clinical data. The sociodemographic data collected were age, smoking habits and alcohol consumption. Clinical data included Absence of Pregnancy, Abortion, Association of Infertility Factors (AIF), Body Mass Index (BMI), Acne, Oiliness, Hirsutism, Hair Loss, History of Polycystic Ovarian Syndrome in the Family (HPCOSF), Use of Hormonal Medication (UHM) and Cardiovascular Diseases (CD).

The genomic DNA was extracted by means of the saline extraction technique, ${ }^{15}$ from $5 \mathrm{~mL}$ of peripheral blood. The Polymerase Chain Reaction (PCR) was performed for analysis of the insertion/deletion polymorphism of the ACE gene (rs1799752), with a final volume of $30 \mu \mathrm{L}$ containing $100 \mathrm{ng}$ genomic DNA, $1 \mathrm{X}$ 
PCR buffer, $1.5 \mathrm{mM} \mathrm{MgCl} 2$, $2 \mathrm{uM}$ of dNTP, 20 pmol of each primer and $1 \mathrm{U}$ of Taq DNA polymerase. The sequences of the primers used were sense: 5' CTG GAG ACC ACT CCC ATC CTT TCT 3' and antisense: 5' GAT GTG GCC ATC ACA TTC GTC AGA T 3'. Amplification conditions were $95^{\circ} \mathrm{C}$ for 10 minutes and 35 cycles of $95^{\circ} \mathrm{C}$ for 45 seconds for denaturation, $63^{\circ} \mathrm{C}$ for 45 seconds for annealing of the primers and $72^{\circ} \mathrm{C}$ for 30 seconds for extension, followed by a final extension at $72^{\circ} \mathrm{C}$ for 10 minutes. PCR products were visualized on $2 \%$ agarose gel coloured with GelRed ${ }^{\circledR}$. The $477 \mathrm{bp}$ products corresponded to the insert (I) and the 190 bp products to the deletion (D) (Figure 1)

In the statistical analysis, the chi-square test was used to analyse the genotypic and allelic distribution of the polymorphisms, as well as to test the Hardy-Weinberg Equilibrium (HWE). The multiple logistic regression model was used to determine the effect of risk factors on PCOS (family history of PCOS, smoking, alcoholism and the presence of polymorphism) and was analysed in 94 patients and 83

FIGURE 1: SCHEMATIC REPRESENTATION OF THE METHODOLOGY USED DURING MOLECULAR ANALYSIS.

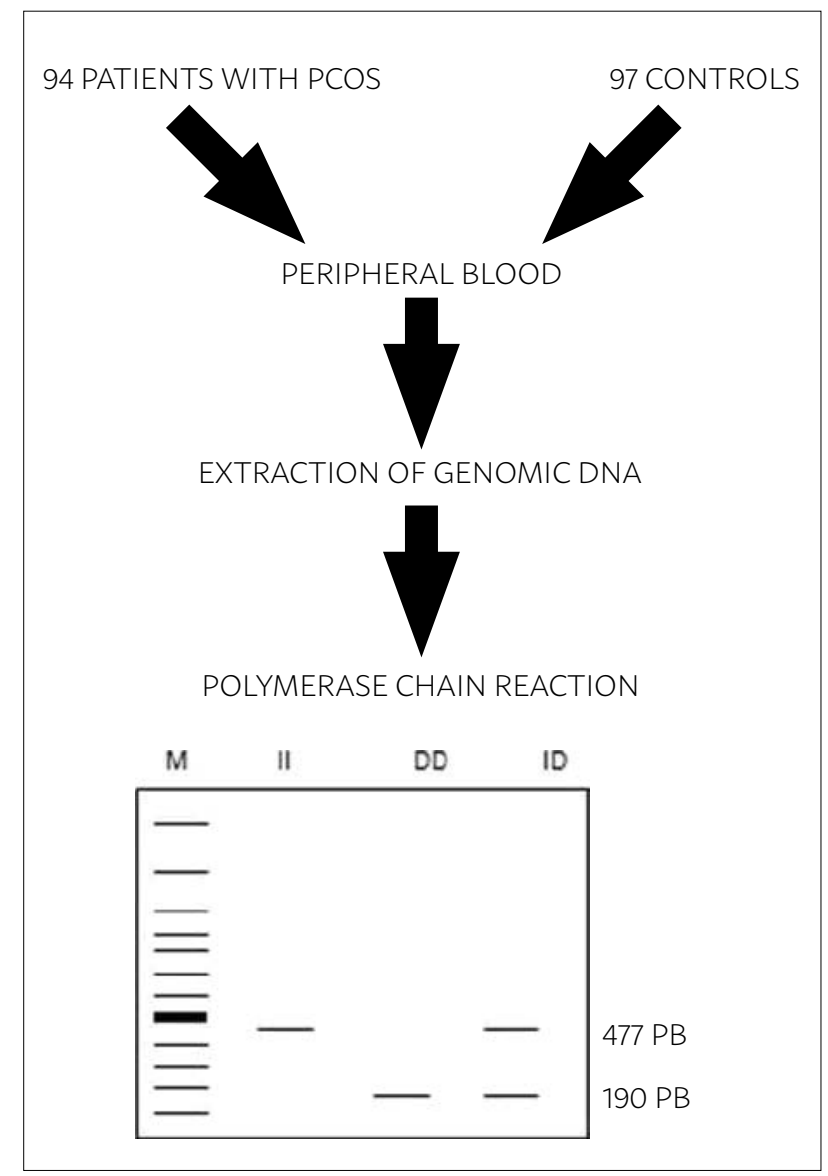

M: represents the $100 \mathrm{pb}$ marker of molecular weight; II: the homozygous genotype for insertion; DD: homozygous genotype for the deletion; ID: heterozygous genotype for insertion/deletion. controls who had all these data. Multiple logistic regression was performed only for the patients and the model included the clinical consequences of PCOS and the polymorphism studied. Multiple logistic regression was also performed in patients in the model that included the biochemical data and the presence of the polymorphism. The results were presented in odds ratio (OR) and 95\% confidence interval (CI 95\%). The level of significance for the analyses was set at $5 \%(p=0.05)$. The statistical power of the sample was $96.8 \%$.

\section{RESULTS}

In the control group $(\mathrm{n}=94), 14.9 \%(14 / 94)$ had genotype II, 30.8\% (29/94) had ID genotype and 54.3\% (51/94) presented the DD genotype. In the patient group, the genotype frequencies were 20.6\% (20/97); $24.7 \%(24 / 97)$ and 54.7\% (53/97), and exhibited genotypes II, ID and DD, respectively. No statistical differences were observed between patients and controls for genotype frequencies $(\chi 2=1.52 ; p=0.47)$. Allelic frequencies were 0.33 and 0.67 for alleles I and $\mathrm{D}$ in patients, and 0.30 and 0.70 in controls, for the same alleles. There were also no differences between allele frequencies $(\chi 2=0.21, p=0.76)$. The distribution of the genotypic frequency was not in HWE for patients $(\chi 2=18.80, p<0.05)$ and for controls $(\chi 2=6.85$, $\mathrm{p}<0.05)$.

Table 1 shows the multiple logistic regression model of risk factors (family history of PCOS, smoking and alcoholism) and the I/D polymorphism of the ACE gene in patients with PCOS and controls. It was evidenced that the family history was more frequent in patients with PCOS (OR=2.56, 95\% CI: 1.26-5.20, $\mathrm{p}<0.05)$, smoking was more frequent in controls (OR=0.18; 95\% CI: 0.07-0.46, $\mathrm{p}<0.05$ ) and there were no differences in alcohol consumption (OR=0.97, 95\% CI: 0.48-1.96, $\mathrm{p}=0.93)$ and in the distribution of polymorphism (OR=0.67, 95\% CI: 0.30-1.51, $\mathrm{p}=0.33$ ).

Table 2 shows the multiple logistic regression model in patients with PCOS and the clinical consequences of the syndrome. There were no differences between the patients with the presence of the polymorphism and the clinical consequences of the disease.

In relation to the biochemical analyses and the presence of polymorphism, no differences were found between the following changes in hormones related to the reproductive cycle - Luteinizing Hormone - LH (OR=0.51, 95\% CI: 0.07-3.55, $\mathrm{p}=0.50$ ); 
TABLE 1: DISTRIBUTION OF POLYMORPHISM OF THE ACE GENE AND RISK FACTORS IN PATIENTS WITH POLYCYSTIC OVARY SYNDROME (PCOS) AND CONTROLS.

\begin{tabular}{|c|c|c|c|c|}
\hline $\begin{array}{l}\text { VARIABLE } \\
\text { ANALYZED }\end{array}$ & $\begin{array}{l}\text { PCOS } \\
n(\%)\end{array}$ & $\begin{array}{l}\text { Controls } \\
\mathrm{n}(\%)\end{array}$ & OR $(95 \% \mathrm{Cl})$ & $\mathrm{p}$ \\
\hline Smoker & & & & $<0.05$ \\
\hline Yes & $07(7.53)$ & $25(28.09)$ & \multirow{2}{*}{$0.18(0.07-0.46)$} & \\
\hline No & $86(92.47)$ & $64(71.91)$ & & \\
\hline Alcohol consumption & & & & 0.93 \\
\hline Yes & $23(24.73)$ & $28(31.46)$ & \multirow{2}{*}{$0.97(0.48-1.96)$} & \\
\hline No & $70(75.24)$ & $61(68.54)$ & & \\
\hline PCOS Family History & & & $2.56(1.26-5.20)$ & $<0.05$ \\
\hline Yes & $35(37.63)$ & $19(21.35)$ & \multirow{5}{*}{$2.56(1.26-5.20)$} & \\
\hline No & $58(62.37)$ & $70(78.65)$ & & \\
\hline Polymorphism of the & & & & 0.33 \\
\hline Yes & $19(20.43)$ & $46(54.76)$ & & \\
\hline No & $74(79.57)$ & $38(45.24)$ & & \\
\hline
\end{tabular}

TABLE 2: DISTRIBUTION OF POLYMORPHISM OF THE ACE GENE AND CLINICAL OUTCOMES IN PATIENTS WITH GENOTYPE ID OR DD.

\begin{tabular}{|c|c|c|c|c|}
\hline $\begin{array}{l}\text { VARIABLE } \\
\text { ANALYZED }\end{array}$ & $\begin{array}{l}\text { Patients with genotype } \\
\text { II } \\
\text { n(\%) }\end{array}$ & $\begin{array}{l}\text { Patients with genotypes } \\
\text { ID or DD } \\
\mathrm{n}(\%)\end{array}$ & O.R $(95 \% \mathrm{Cl})$ & $\mathrm{p}$ \\
\hline Absence of Pregnancy & & & $2.61(0.42-16.19)$ & \\
\hline Yes & $06(31.6)$ & $14(18.9)$ & & 0.30 \\
\hline No & $13(68.4)$ & $60(81.1)$ & & \\
\hline Abortion & & & $0.23(0.02-2.63)$ & \\
\hline Yes & $\mathrm{O} 3(15.8)$ & $03(4.1)$ & & 0.24 \\
\hline No & $16(84.2)$ & $71(95.9)$ & & \\
\hline Menstrual Irregularity & & & $1.04(0.18-6.01)$ & 0.96 \\
\hline Yes & $14(73.7)$ & $42(56.8)$ & \multirow{5}{*}{$4.40(0.38-51.08)$} & \multirow{5}{*}{0.24} \\
\hline No & $05(26.3)$ & $32(43.2)$ & & \\
\hline \multicolumn{3}{|c|}{ Factors Associated with Infertility } & & \\
\hline Yes & $01(5.3)$ & $11(14.9)$ & & \\
\hline No & $18(94.7)$ & $63(85.1)$ & & \\
\hline Use of Hormone Medication & & & $1.19(0.25-5.59)$ & 0.83 \\
\hline Yes & $09(47.4)$ & $43(58.1)$ & & \\
\hline No & $10(52.6)$ & $31(41.9)$ & & \\
\hline Hirsutism & & & $014(0.02-1.11)$ & 0.06 \\
\hline Yes & $14(73.7)$ & $37(50)$ & & \\
\hline No & $05(26.3)$ & $37(50)$ & & \\
\hline Acne & & & $1.33(0.23-7.85)$ & 0.75 \\
\hline Yes & $11(57.9)$ & $48(64.9)$ & & \\
\hline No & $08(42.1)$ & $26(35.1)$ & & \\
\hline Oiliness & & & $0.77(0.12-5.09)$ & 0.79 \\
\hline Yes & $15(78.9)$ & $57(77.0)$ & & \\
\hline No & $04(21.1)$ & $17(23.0)$ & & \\
\hline Hair Loss & & & $2.82(0.62-12.83)$ & 0.18 \\
\hline Yes & $11(57.9)$ & $46(62.2)$ & & \\
\hline No & $08(42.1)$ & $28(37.8)$ & & \\
\hline
\end{tabular}

Follicle stimulating hormone - FSH (OR=2.78, 95\% CI: 0.20-38.2, $\mathrm{p}=0.44)$; Inverted LH/FSH function (OR=0.52, 95\% CI: 0.05-5.14, p=0.58) and testosterone (OR=1.05, 95\% CI: 0.23-4.87, p=0.95) and presence of the polymorphism.

\section{DISCUSSION}

It is known that the ACE enzyme plays an important role in the renin-angiotensin system that regulates blood pressure, as well as participate in the angiogenesis of the ovarian epithelium, follicular 
growth, steroidogenesis and inflammation. ${ }^{7}$ The ACE gene insertion/deletion polymorphism is associated with changes in plasma protein concentration. The presence of the $\mathrm{D}$ allele results in high plasma levels of the protein, which subsequently leads to an elevation of angiotensin II levels and alterations in the synthesis of steroid hormones. ${ }^{8}$

In the present study, the univariate analysis found no association between polymorphism and PCOS, which is in agreement with the study by Sun et al. ${ }^{16}$ in 2010, which evaluated 142 patients and 100 controls and did not observe differences between the groups. However, a study in the Turkish population that analysed 100 patients with PCOS and 100 controls, and a Polish study with 138 patients and 110 controls showed differences between the groups using the same analysis, indicating that the deletion may be a risk factor for PCOS. ${ }^{17,18}$

Our results are according to a study in South India with 582 women of reproductive age (346 with PCOS and 236 controls) who found no association between the I/D polymorphism in the ACE and PCOS, but the multiple logistic regression analysis found an association of the deletion polymorphism with age of onset of disease and acanthosis. ${ }^{19}$ In our study multiple logistic regression analysis was performed and no differences were detected between the clinical consequences of PCOS analysed (clinical hyperandrogenism, pregnancy-related problems), and presence of the polymorphism. However, the age at onset of the disease and the presence of acanthosis were not analysed as in the work performed in South India.

Regarding the genotypic distribution, the sample studied was not in Hardy-Weiberng equilibrium (HWE). One of the possible explanations is that this result can be due to the random selection of the studied individuals, inheritance model of the adopted disease and random changes in the genotype frequencies due to sample errors or sample size (genetic drift). ${ }^{20-22}$

In the present study, the multiple logistic regression model evidenced an increased frequency of smoking in the control group, which is not in agreement with a study that evaluated the effect of smoking in women with PCOS and concluded that they are at increased risk for developing endocrine dysfunctions and other diseases associated with the syndrome when smokers. ${ }^{16}$ Our study also showed an increased frequency of family recurrence of PCOS in the study group, which is in agreement with the literature that shows that PCOS is a multi- factorial disease with genetic factors in its aetiology. Studies with twins have shown that a mother or sister with PCOS favours a $30 \%-50 \%$ risk of developing PCOS. ${ }^{4}$

The work of Sun et al. ${ }^{16}$ of 2010 did not show an association of the I/D polymorphism in the ACE gene with PCOS, however, differences in testosterone concentration among the three genotypes were observed in patients and controls. In our study, no association was found between the presence of the polymorphisms and the biochemical test data analysed.

A study of 801 patients with PCOS subdivided into three groups (A: patients with biochemical hyperandrogenism and other diagnostic criteria for PCOS; B: patients with clinical hyperandrogenism and other characteristics and C: group with anovulation and presence of cysts without manifestations of hyperandrogenism) showed differences between groups A and $\mathrm{B}$ in the distribution of the polymorphism compared to the control group. The group without manifestations of hyperandrogenism (group C) did not present any difference when compared to the control group. Genotype II was also positively correlated with Homa-IR (Homeostasis model assessment, calculated by Glycaemia (mMol) x Insulin $(\mathrm{uU} / \mathrm{mL})$ $\div 22.5$ ) and Quicki (Quantitative insulin sensitivity check index, by $1 \div\left(\right.$ Log insulin + Log glycaemia) ${ }^{23} \mathrm{~A}$ study carried out in the Turkish population showed an association of the DD genotype with the plasma insulin concentration and the Homa-IR index..$^{24}$ Our patients were not divided according to the diagnostic criteria and insulin was not measured in all patients for the calculation of Homa-IR and Quicki indexes, which is one of the limitations of our study.

The meta-analysis performed by Jia et al. ${ }^{13}$ in 2013 showed no association of polymorphisms with PCOS in the general population. Only after stratification in ethnicities, it was concluded that the polymorphism is associated with the disease in Caucasian women, but it is not related in Asian women. ${ }^{10}$ Our study did not perform the categorized assessment by ethnic groups due to the fact that the Brazilian population has a genomic heterogeneity due to process of miscegenation since the discovery of the country. The study by Pena et al. ${ }^{25}$, conducted in 2011, analysed 934 Brazilian women categorized with white, brown and black skin colour in a panel containing 40 insertion and deletion polymorphisms. The researchers concluded that the Brazilian population of different regions is more uniform than expected. 


\section{CONCLUSION}

In conclusion, in the sample studied there is no association of the I/D polymorphism of the ACE gene and PCOS. Acknowledgments: This work was

supported by the Fapemig - (Process APQ 01608-14) and CNPq (Process 476423/2013-9). The authors also thanks to Evaldo Maia to collected of blood samples

\section{RESUMO}

OBJETIVO: Investigar a contribuição do polimorfismo de deleção e inserção (rs1799752) do gene enzima conversora de angiotensina (ECA) na etiologia da Síndrome dos Ovários Policísticos (SOP).

MÉTODOS: Participaram deste estudo 97 mulheres diagnosticadas com SOP, atendidas no ambulatório de Ginecologia e Obstetrícia do Hospital de Clínicas da UFTM. O grupo controle foi constituído por 94 mulheres. Todas as participantes foram submetidas à coleta de $10 \mathrm{~mL}$ de sangue total e o DNA genômico foi obtido pelo método de extração salina. A genotipagem das amostras foi realizada por meio da Reação da Cadeia da Polimerase (PCR). A análise estatística foi realizada por análises descritivas, análise univariada e modelo de regressão logística. Os resultados foram apresentados em odds ratio (OR) e intervalo de confiança de 95\% (IC - 95\%). Foi

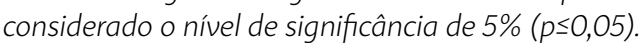

RESULTADOS: Não foram observadas diferenças estatísticas entre pacientes e controles para as frequências genotípicas ( $\chi 2=1,52 ; p=0,47)$ e alélicas $(\chi 2=0,21 ; p=0,76)$. A distribuição da frequência genotípica não está em equilíbrio de HWE para as pacientes ( $\chi^{2}=18,80$; $p<0,05)$ e para controles $\left(\chi^{2}=6,85 ; p<0,05\right)$. Em relação aos fatores de risco para a síndrome, a história familial de SOP é mais frequente entre as pacientes.

CONCLUSÃO: Na casuística estudada não há associação do polimorfismo I/D do gene ACE e SOP.

PALAVRAS-ChAVE: Síndrome do ovário policístico. Cistos ovarianos. Polimorfismo genético. Angiotensinas.

\section{REFERENCES}

1. Bani Mohammad M, Majdi Seghinsara A. Polycystic ovary syndrome (PCOS), diagnostic criteria, and AMH. Asian Pac | Cancer Prev. 2017;18(1):17-21.

2. Andrade VH, Mata AM, Borges RS, Costa-Silva DR, Martins LM, Ferreira PM, et al. Current aspects of polycystic ovary syndrome: a literature review. Rev Assoc Med Bras. 2016;62(9):867-71.

3. De Leo V, Musacchio MC, Cappelli V, Massaro MG, Morgante G, Petraglia F. Genetic, hormonal and metabolic aspects of PCOS: an update. Reprod Biol Endocrinol. 2016;14(1):38.

4. Azziz R, Carmina E, Chen Z, Dunaif A, Laven JS, Legro RS, et al. Polycystic ovary syndrome. Nat Rev Dis Primers. 2016;2:16057.

5. Norman RJ, Davies MJ, Lord J, Moran LJ. The role of lifestyle modification in polycystic ovary syndrome. Trends Endocrinol Metab. 2002;13(6):251-7.

6. Deligeoroglou E, Kouskouti C, Christopoulos P. The role of genes in the polycystic ovary syndrome: predisposition and mechanisms. Gynecol Endocrinol. 2009;25(9):603-9.

7. Palumbo A, Ávila I, Naftolin F. The ovarian renin-angiotensin system (OVRAS): a major factor in ovarian function and disease. Reprod Sci. 2016;23(12):1644-55.

8. Rigat B, Hubert C, Alhenc-Gelas F, Cambien F, Corvol P, Soubrier F. An insertion/deletion polymorphism in the angiotensin l-converting enzyme gene accounting for half the variance of serum enzyme levels. J Clin Invest. 1990;86(4):1343-6.

9. Sayed-Tabatabaei FA, Oostra BA, Isaacs A, van Duijn CM, Witteman JC. ACE polymorphisms. Circ Res. 2006;98(9):1123-33.

10. Al-Saikhan Fl, Abd-Elaziz MA, Ashour RH. Association between risk of type 2 diabetes mellitus and angiotensin-converting enzyme insertion/ deletion gene polymorphisms in a Saudi Arabian population. Biomed Rep. 2017;7(1):56-60

11. Sun F, He N, Zhang K, Wu N, Zhao J, Qiu C. Association of ACE gene A2350G and I/D polymorphisms with essential hypertension in the northernmost province of China. Clin Exp Hypertens. 2018;40(1):32-8.

12. Herrera CL, Castillo W, Estrada P, Mancilla B, Reyes G, Saavedra N, et al. Association of polymorphisms within the renin-angiotensin system with metabolic syndrome in a cohort of Chilean subjects. Arch Endocrinol Metab. 2016;60(3):190-8

13. Jia $\mathrm{H}$, Wang $\mathrm{B}, \mathrm{Yu} \mathrm{L}$, Jiang Z. Association of angiotensin-converting enzyme gene insertion/deletion polymorphism with polycystic ovary syndrome: a meta-analysis. J Renin Angiotensin Aldosterone Syst. 2013;14(3):255-62.
14. Rotterdam ESHRE/ASRM-Sponsored PCOS consensus workshop group Revised 2003 consensus on diagnostic criteria and long-term health risks related to polycystic ovary syndrome (PCOS). Hum Reprod. 2004;19(1):41-7.

15. Miller SA, Dykes DD, Polesky HF. A simple salting out procedure for extracting DNA from human nucleated cells. Nucleic Acids Res. 1988;16(3):1215.

16. Sun L, Lv H, Wei W, Zhang D, Guan Y. Angiotensin-converting enzyme $D / I$ and plasminogen activator inhibitor-1 4G/5G gene polymorphisms are associated with increased risk of spontaneous abortions in polycystic ovarian syndrome. J Endocrinol Invest. 2010;33(2):77-82.

17. Bayram B, Kılıççı C, Onlü H, Ozkurt M, Erkasap N, Yıldırım E, et al. Association of angiotensin converting enzyme (ACE) gene I/D polymorphism and polycystic ovary syndrome (PCOS). Gene. 2011;489(2):86-8.

18. Ożegowska K, Bogacz A, Bartkowiak-Wieczorek|, Seremak-Mrozikiewicz $A$, Pawelczyk L. Association between the angiotensin converting enzyme gene insertion/deletion polymorphism and metabolic disturbances in women with polycystic ovary syndrome. Mol Med Rep. 2016;14(6):5401-7.

19. Deepika ML, Reddy KR, Rani VU, Balakrishna N, Latha KP, Jahan P. Do ACE I/D gene polymorphism serve as a predictive marker for age at onset in PCOS? J Assist Reprod Genet. 2013;30(1):125-30.

20. Xu J, Turner A, Little J, Bleecker ER, Meyers DA. Positive results in association studies are associated with departure from Hardy-Weinberg equilibrium: hint for genotyping error? Hum Genet. 2002;111(6):573-4.

21. Llorca J, Prieto-Salceda D, Combarros O, Dierssen-Sotos T, Berciano J. Competing risks of death and Hardy-Weinberg equilibrium in case-control studies of gene-disease association. Gac Sanit. 2005;19(4):321-4.

22. Wittke-Thompson IK, Pluzhnikov A, Cox N). Rational inferences about departures from Hardy-Weinberg equilibrium. Am J Hum Genet. 2005;76(6):967-86.

23. Koika V, Georgopoulos NA, Piouka A, Roupas ND, Karela A, Armeni AK, et al. Increased frequency of the DI genotype of the angiotensin-I converting enzyme and association of the II genotype with insulin resistance in polycystic ovary syndrome. Eur | Endocrinol. 2012;166(4):695-702.

24. Celik O, Yesilada E, Hascalik S, Celik N, Sahin I, Keskin L, et al. Angiotensin-converting enzyme gene polymorphism and risk of insulin resistance in PCOS. Reprod Biomed Online. 2010;20(4):492-8.

25. Pena SD, Di Pietro G, Fuchshuber-Moraes M, Genro IP, Hutz MH, Kehdy FS, et al. The genomic ancestry of individuals from different geographical regions of Brazil is more uniform than expected. PLoS One. 2011;6(2):e17063. 